\title{
The Term Structure of Interest Rates and Monetary Policy during a Zero Interest Rate Period
}

\author{
Jun Nagayasu
}

This paper empirically evaluates the validity of the term structure of interest rates in a low interest rate environment using high-frequency Japanese data. Allowing for the time-varying term premium, we obtain evidence that when interest rates are low and the short end of the term structure is studied, there is no evidence to support the term-structure relationship. This poor performance is attributed to little information in the interest rate spread that can be used to predict future economic activity andlor to the absence of the persistent term premium. In contrast, some evidence for the term-structure relationship is found when the long end of the term-structure data is considered during a relatively high interest rate period.

Keywords: Monetary policy; Zero interest rates

JEL Classification: E41, E52

Statistics Department, International Monetary Fund and Institute of Policy and Planning Sciences, University of Tsukuba

This paper was written while I was visiting the Institute for Monetary and Economic Studies (IMES) at the Bank of Japan. I would like to thank IMES for providing me with an excellent research environment. This paper has benefited from comments and input by Taimur Baig, Yasushi Iwamoto, Yukinobu Kitamura, Shin-ichi Nishiyama, Kunio Okina, Tsutomu Ota, Makoto Saito, Toshitaka Sekine, Shigenori Shiratsuka, and seminar participants at IMES. I would also like to thank Hiroyuki Oi for his research assistance. However, any remaining errors and omissions are my own. The views presented here are mine and do not necessarily reflect the views or policies of the Bank of Japan, IMES, or the International Monetary Fund. 


\section{Introduction}

Since the Japanese asset bubble burst in early 1990 and during the subsequent economic recession, expansionary fiscal and monetary policies have been implemented in an attempt to stimulate the Japanese economy. Up to early 2003, however, there had been no strong signals of economic recovery, at least at the macroeconomic level (e.g., in prices and GDP). ${ }^{l}$ On the contrary, these policies have generated some difficulties that seem to constrain the authorities from implementing further expansionary measures. Notably, the (net) government debt-to-GDP ratio, which stood at 13 percent in 1991, exceeded an estimated 72 percent in 2002 (International Monetary Fund [IMF] [2003]), making it the highest among industrialized countries, and it continues to grow. With respect to interest rates, short-term rates have hovered around zero percent since the mid-1990s.

Given the high government debt and the zero lower bound on nominal interest rates, a question frequently posed to policymakers is how to facilitate Japan's economic recovery. Recent debate has centered around the use of monetary policy (e.g., Goodfriend [2001]). This is due to the fact that even though nominal shortterm interest rates have almost reached zero percent and cannot fall further owing to the non-negativity constraint, ${ }^{2}$ it is still possible to conduct more accommodative monetary policies by injecting liquidity into the market (Meltzer [1999]). ${ }^{3}$ The effects of such an easing policy could be transmitted through expectations, credit, the exchange rate, and portfolio rebalancing channels. This viewpoint has been both theoretically developed and supported by simulation results. But until very recently, there has been little empirical research in this area using actual data, and in general we do not possess detailed knowledge regarding the effectiveness of monetary policy at the intermediate level. ${ }^{4}$

The intermediate effects of monetary policy can be examined by looking at the above-mentioned transmission channels, including the interest rate channel, which the Bank of Japan (BOJ) could use to influence the real economy. Current research on this subject is frequently based on the term structure of interest rates (i.e., the relationship between interest rates with different maturities). The term-structure model focuses

1. Kimura et al. (2002) examine the impact of an increase in the monetary base on the Japanese economy using the autoregressive (AR) vector model. By estimating a model with time-varying parameters, they conclude that an increase in Japan's monetary base did not influence price movements significantly during the recent low interest rate period. Similarly, a need for substantial and sustainable monetary easing is discussed as a means of combating deflation (Baig [2003]).

2. Nominal interest rates do not become negative because of the existence of transaction costs and cash. However, there are some instances when short-term rates became negative in the United States during the Great Depression (Cecchetti [1988]).

3. The influence of monetary policy under low interest rates may be limited, however, because its effectiveness relies heavily on changes in expected inflation (e.g., Blinder [2000], Goodfriend [2001], and Reifschneider and Williams [2000]). Furthermore, Jung, Teranishi, and Watanabe (2001) demonstrate that such a zero interest rate policy needs to be implemented for a considerable time (even after the economy returns to a normal level) to generate higher expected inflation, lower long-term nominal interest rates, and domestic currency depreciation. This study thus indicates that the duration of the implementation of the zero interest rate policy was an important factor in making such a policy credible.

4. Here the effectiveness of monetary policy at the intermediate level refers to the influence of monetary policy on agents' expectations, equities, etc., which are likely to be affected before a change in price or GDP occurs. 
mainly on the interest rate and expectations channels. ${ }^{5}$ For example, Okina and Shiratsuka (2004) studied the expectations channel of recent expansionary monetary policies. ${ }^{6}$ By calculating the slope of yield curves for returns on financial assets with different maturities, they provide evidence in favor of the BOJ's commitment to maintaining low interest rates. Fujiki and Shiratsuka (2002), in addition, point out the importance of liquidity effects in maintaining low interest rates during a zero interest rate period. By contrast, Hosono, Sugihara, and Mihira (2001) conclude that the announcement effect of the zero interest rate policy was limited and did not influence long-term rates. ${ }^{7}$

Against this background, this paper analyzes the validity of the term-structure model in different sample periods. In contrast to previous research that has often employed an event-study approach, a time-series method is used here to obtain the more persistent implications of monetary policy. We provide empirical evidence to support the term-structure relationship when the long end of the term structure is studied at a time of high interest rates. This relationship, however, diminishes as interest rates are lowered and the short end of its relationship is analyzed. This is consistent with economic theory and, we argue, attributable to there being less information in the yield spread that is useful for predicting future events and/or the absence of the persistent term premium. Although this study focuses solely on the Japanese experience, it has policy implications for other industrialized countries that have also reduced interest rates to low levels.

The rest of the paper is organized as follows. Section II summarizes recent Japanese monetary policies. Section III reviews the theoretical relationship between interest rates with different maturity lengths and looks at literature that empirically investigated this model using Japanese economic data. Section IV explains the statistical methodology, the generalized method of moments (GMM), which is used to estimate the term-structure model. Section V reports a preliminary analysis of our data, while Section VI examines the validity of the term-structure model. The paper concludes with Section VII, which discusses some policy implications related to this paper's findings.

\section{History of Monetary Policy since 1990}

The Japanese economy went into recession after the bubble burst in 1990. The Nikkei Stock Average, which recorded its highest-ever level $(¥ 38,916)$ in December 1989 , started to decline in January 1990. The BOJ has implemented several measures to facilitate economic recovery since that time. These policies can be summarized and categorized broadly into four sub-periods.

5. Needless to say, many factors other than interest rates and expectations could affect the term spreads.

6. See the next section for a definition of "low interest rate."

7. Furthermore, Nagayasu (2003) investigates a narrow definition of the portfolio channel by focusing on the relationship between equity returns and interest rates. He shows that the BOJ's ability to affect equity indices has declined substantially since 1999 , when short rates reached almost zero percent. 
(1) Transition period A: This was a period when (short- and/or long-term) interest rates exhibited a declining trend. Until 1995, the official discount rate was one of the main instruments used to conduct monetary policy. An expansionary policy started on July 1, 1991 when the official discount rate was dropped from 6.0 to 5.5 percent. This rate continued to fall and became 0.5 percent on September 8, 1995. On March 31, 1995, the BOJ decided that the uncollateralized call rate should be an operating target of monetary policy.

(2) Transition period B: This period generally covered a low interest rate period prior to the implementation of the zero interest rate policy. While the interest rate in this period was not as low as that during the zero interest rate period, it was still very low from a historical perspective. On July 7, 1995, provisions made to increase liquidity were aimed at moving the call rate below the discount rate. Furthermore, the failure of several major financial institutions in late 1997 increased market concern regarding credit and liquidity risks. ${ }^{8}$ To ease the upward market pressure, the $\mathrm{BOJ}$ introduced several measures including a so-called dual system through which long-term bonds were purchased and short-term assets (e.g., Treasury bills) were sold simultaneously. In addition, since 1998, the call rate target level has been announced to the public. On September 9, 1998, the uncollateralized overnight call rate was targeted at 0.25 percent on average.

(3) The zero interest rate policy period: This is a period when the BOJ adopted the zero interest rate policy. Sluggish economic recovery led the BOJ to implement this policy from February 12, 1999, under which the target rate for uncollateralized overnight calls was aimed at close to zero percent. Under this policy, the BOJ provided the market with ample liquidity to keep the short-term rate close to zero percent. This policy was abandoned on August 11, 2000 and the target level raised to around 0.25 percent, when signs of economic recovery were thought to be in sight.

(4) The quantitative easing policy period: This period covers observations in which a different operating target for money market operations, the so-called quantitative easing policy, was implemented. Under this monetary policy, the $\mathrm{BOJ}$ targets the outstanding balance of the BOJ's current account. ${ }^{9}$ Even with short-term rates near zero percent, the $\mathrm{BOJ}$ can conduct further expansionary monetary policy by injecting liquidity into the market. This in turn could induce a reduction in long-term rates and cause the yen to depreciate, for instance. Furthermore, in contrast to the zero interest rate policy, in theory, short-term interest rates are determined endogenously and therefore are expected to exhibit more fluctuation, not necessarily remaining at zero percent. The quantitative easing policy is expected to remain until the consumer price index (CPI), excluding perishables, records a year-on-year increase of zero percent or more on a sustainable basis (IMF [2003]).

8. These institutions included Sanyo Securities, Yamaichi Securities, and Hokkaido Takushoku Bank.

9. This mainly constitutes the reserve deposit balance held by private financial (both depository and nondepository) institutions. 
The target level of the current account balance has been increased several times: the initial level of $¥ 5$ trillion was raised to $¥ 27-30$ trillion in May 2003. This expansionary policy resulted in a year-on-year increase in M1 of 3.5 percent in 2000, 14 percent in 2001, and more than 20 percent in 2002. However, the increasing trend in $\mathrm{M} 1$ was not translated into $\mathrm{M} 2+\mathrm{CD}$ (broad money) data that exhibited less than a 4 percent increase during these periods (IMF [2003]).

The quantitative easing policy has been conducted through open market operations by purchasing financial assets. Government debt securities can be bunched into roughly four groups based on their terms to maturity; Treasury bills (a maturity of one year or less), medium-term government bonds (two to five years), long-term government bonds (six to 10 years), and super-long-term government bonds (more than 10 years). As part of the quantitative easing policy, the BOJ has been purchasing these Japanese government bonds (JGBs). ${ }^{10}$ Furthermore, the BOJ has been raising its target level for the amount of long-term Japanese government securities it intends to purchase outright. Initially, the amount was targeted at $¥ 400$ billion per month, but was increased to $¥ 1.2$ trillion per month in October 2002. As a result, government debt securities have come to dominate Japan's bond market in recent years.

These recent accommodative policies, which led the short-term interest rates to around zero percent from 6 percent in early 1990 and similarly the yield of the long-term government bonds from 7 percent to less than 1 percent, are extremely expansionary in terms of nominal interest rate levels. Certainly, these policies have no precedent in Japanese history and there are few examples worldwide where interest rates have fallen to such a low level.

For convenience, this paper will use the term "low interest rate" policy (period) to refer to both "zero interest rate" and "quantitative easing" policies (periods), since they both, directly or indirectly, attempt to keep the call rate at or near zero percent.

\section{Term Structure of Interest Rates}

The relationship between interest rates with different maturities can be summarized using the term structure of interest rates, which is frequently used to study the effects of monetary policy. While the rational expectations version of this model has received some criticism (to be reviewed shortly), it has also been used to rationalize recent monetary policies. In this regard, the rational expectations model is a good starting point for this paper's analysis.

For non-coupon financial assets, this model can be derived using the following behavioral equations. First, we define the relationship between the long-term interest rate $\left(R_{n, t}\right)$ and the forward interest rate $\left(f_{j, t}\right)$ as ${ }^{I I}$

10. Meltzer (1999) also argues for conducting open market operations by purchasing other assets such as foreign currency government bonds.

11. Shiller (1979) developed a more generalized relationship between short- and long-term rates, which incorporates a coupon effect. 


$$
R_{n, t}=\frac{1}{n} \sum_{j=0}^{n-1} f_{j t}
$$

where $n(n>1)$ and $j$ represent the maturity length. Furthermore, when $R_{1, t+j}=r_{1, t+j}$ and $f_{1, t}=E_{t}\left(r_{1, t+j}\right)+\phi_{j}$, where $r_{1, t+j}$ is a short-term rate at time $t+j, E()$ is the expectations operator, and $\phi_{j}$ is a forward-term premium that is time-invariant, ${ }^{12}$ equation (1) can be written as

$$
R_{n, t}=\frac{1}{n} \sum_{j=0}^{n-1} E_{t}\left(r_{1, t+j}\right)+\phi_{n}
$$

where $\phi_{n}=\sum_{j=0}^{n-1} \phi_{j} / n$. Equation (2) states that the long-term rate at time $t$ is the average of the expected future short-term rates plus the term premium. When $\phi_{n}=0$, this equation becomes consistent with the pure expectations model. However, since $\phi_{n}=0$ represents a very unique situation, this restrictive assumption is relaxed for the subsequent part of this paper.

The term-structure model has some important policy implications in understanding the intermediate effects of monetary policies recently implemented by the BOJ. First of all, accommodative monetary policies are expected to result in a reduction of both expected short-term rates and the long-term rate. ${ }^{13}$ This supposition is applicable during the transition periods when the short-term rates have not yet reached zero percent. Once a zero interest rate policy is implemented and short-term rates are therefore near zero percent, a successful policy should result in expected future short-term interest rates of zero percent (i.e., $E_{t} r_{1, t}, E_{t} r_{1, t+1} \ldots=0$ ). In this case, the long-term rate becomes equal to the forward-term premium. This is an extreme example of Ruge-Murcia (2002), who shows that the zero lower bound on nominal interest rates induces a nonlinear relationship between long- and short-term interest rates. In other words, the long-term interest rate will respond asymmetrically to a change in the short-term rate. This reduces considerably the central bank's power to influence long-term interest rates during the low interest rate period. In contrast, a failure of monetary policy would result in an increase in expected short-term rates, which would tend to raise the long-term interest rate.

The second implication of the term-structure model can be summarized using the following equation that can be derived by manipulating equation (2):

12. Shiller (1990) summarizes the definition of three types of risk premiums; namely, the forward term premium, the holding period term premium, and the rollover term premium. The derivation of a risk premium refers by definition to the forward term premium, which is defined as the difference between the forward rate and the expectation of the corresponding future spot rates.

13. This assumption may be subject to criticism since economic recovery, a goal of monetary policy, is expected to increase expected inflation and thus future short-term interest rates, which in turn will raise long-term interest rates. However, since the zero interest rate policy had been in operation for 18 months and the quantitative easing policy for two years at the time of writing, it seems appropriate to assume that a medium-term or intermediate target of monetary policy is to reduce long-term interest rates through the mechanism explained in equation (2). Ogawa and Takenaka (2001) argue that monetary policy mechanisms take one to two years to achieve their full effect. 


$$
R_{n, t}-r_{1, t}=\frac{1}{n} \sum_{j=1}^{n-1} \sum_{i=1}^{j} E_{t}\left(\Delta r_{1, t+i}\right)+\phi_{n}
$$

where $\Delta r_{1, t+i}=r_{1, t+i}-r_{1, t+i-1}$. That is to say, accommodative monetary policy is expected to reduce changes in expected short-term rates during the transition periods. In these circumstances, equation (3) furthermore suggests that the yield spread should also decline, other things being constant. When the change in expected short-term rates is zero percent, the size of the yield spread should approach that of the term premium. In this case, no significant relationship between the long- and short-term interest rates exists.

Equation (3) has two important statistical implications. First, when the first difference of the short-term rate is stationary (i.e., $\left.\Delta r_{1, t+i} \sim I(0)\right)$, so is the yield spread, $R_{n, t}-r_{1, t} \sim I(0)$. It follows that when $R_{n, t}$ follows the unit root process, $R_{n, t}$ and $r_{1, t}$ are cointegrated (Campbell and Shiller [1987]). Another implication of equation (3) is related to the direction of causality between the yield spread and short-term interest rates. It suggests that the current yield spread should contain information useful in predicting future short-term rates. It is important to note that this type of unique causality may exist during the transition period, but we do not expect any unique causality when interest rates are low. This is obvious from equation (2), which can be simplified to show a direct relationship between the long-term rate and the term premium when monetary policy is credible and thus the expected short-term rates equal zero.

Generally, there is little evidence to support the standard term-structure model. Campbell and Hamao (1992) study the short end of the term structure and provide evidence to support the expectations theory, particularly in the period preceding 1985. However, the performance of the model deteriorates after 1985, when changes in policy dictated by the Plaza Accord resulted in a regime shift in the data. ${ }^{14}$ The poor performance of the standard model is due to the existence of a time-varying term premium (Shikano [1985] and Shirakawa [1987])..$^{15}$ Using a cointegration method, Nagayasu (2002) studies the long-run implications of the short end of the term structure, providing evidence to support expectations theory while making allowances for the stationary time-varying term premium. ${ }^{16}$

Previous research has shown the importance of modeling the time-varying term premium. This paper therefore incorporates it and in addition considers the policy reaction function of the BOJ. McCallum (1994) proposes that equation (2) be re-expressed by including the time-varying term premium that follows the AR(1) process.

14. Thornton (2004) obtains the same result using a similar approach.

15. A further possible cause of the failure of the expectations model is identified by Saito et al. (2001), who outline the importance of the liquidity effect of periodic settlement on the term structure. They document that such an effect is prevalent at the end of settlement months (March, September, and December).

16. Kikugawa and Singleton (1994) caution that coupon effects have significant influence when applying the standard expectations theory to JGB data. 


$$
R_{n, t}=\frac{1}{n} \sum_{j=0}^{n-1} E_{t}\left(r_{1, t+j}\right)+\phi_{t}, \quad \text { where } \phi_{t}=\rho \phi_{t-1}+\epsilon_{t}
$$

where $\epsilon_{t} \sim$ i.i.d. $\left(0, \sigma_{\epsilon}^{2}\right)$, and $|\rho|<1$. The parameter, $\rho$, measures the persistence level of the term premium. Furthermore, the central bank's policy reaction function can be summarized as

$$
r_{1, t}=\alpha r_{1, t-1}+\beta\left(R_{n, t}-r_{1, t}\right)+u_{t}
$$

The residual term, $u_{t}$, captures indicators other than the yield spread that also contain some useful information on future economic activities. Here, for simplicity, this residual is assumed to be an i.i.d. process $\left(u_{t} \sim\right.$ i.i.d. $\left.\left(0, \sigma_{u}^{2}\right)\right)$. Equation (5) measures the BOJ's attempts to smooth short-term interest rate movements. A value of $\alpha$ close to one suggests that the short-term interest rates between $t$ and $t-1$ are closely correlated. A positive $\beta$ reflects the BOJ's action to tighten monetary policy. This is a case where a widening spread indicates higher expected future economic activity and inflation. Kim and Limpaphayom (1997) analyze the ability of the spread to explain economic growth, and Nagayasu (2002) studies the predictability of future inflation based on the yield spread. These studies confirm that a widening yield spread indicates a rise in future economic activity and inflation, respectively, when interest rates are high. In contrast, $\beta=0$ signals that the $\mathrm{BOJ}$ did not respond to the current state of the yield spread but simply attempted to smooth short-term interest (Mankiw and Miron [1986]).

Short-term interest rates can be assumed to behave in line with the following process: $r_{1, t}=\theta_{1} r_{1, t-1}+\theta_{2} \phi_{t-1}+\theta_{3} u_{t}$. Using this expression, McCallum (1994) and Kugler (1997) show that expected short-term rates can be expressed as

$$
\begin{aligned}
& E r_{1, t+1}=\theta_{1, r_{1, t-1}}+\theta_{2} \phi_{t}+\theta_{3} u_{t}+\theta_{2} \rho \phi_{t}, \\
& E r_{1, t+2}=\theta_{1} r_{1, t-1}+\theta_{2} \phi_{t}+\theta_{3} u_{t}+\theta_{2} \rho \phi_{t}+\theta_{2} \rho^{2} \phi_{t}, \text { and } \\
& E r_{1, t+j}=\theta_{1} r_{1, t-1}+\theta_{2}\left(1+\rho+\cdots+\rho^{j}\right) \phi_{t}+\theta_{3} u_{t} .
\end{aligned}
$$

Based on these expected values and using equations (3), (4), and (5) as well as the minimal-state-variables criterion discussed by McCallum (1994), Kugler (1997) derives solutions for parameters $\left(\theta_{1}, \theta_{2}\right.$, and $\left.\theta_{3}\right)$. Then, the following equations can be obtained: ${ }^{17}$

$$
R_{n, t}-r_{1, t}=\rho\left(R_{n, t-1}-r_{1, t-1}\right)+\frac{n}{n-\beta \sum_{j}^{n-1}(n-j) \rho^{j}} \epsilon_{t},
$$
not estimate such a model, because it fails to convert using the maximum likelihood method. 


$$
r_{1, t}-r_{1, t-1}=\mu\left(R_{n, t-1}-r_{1, t-1}\right)+\frac{n \beta}{n-\beta \sum_{j}^{n-1}(n-j) \rho^{j}} \epsilon_{t}+u_{t}
$$

where $\mu=\rho \beta$. Since equation (3) cannot be directly estimated due to the existence of unobservable components, this paper tests the theoretical implications of monetary policy using equation (7). Obviously, $\mu=0$ holds when $\rho$ and/or $\beta$ are equal to zero.

Using this framework, Kugler (1997) has found the existence of a persistent term premium as well as a strong tendency of the BOJ to react toward the yield spread variances between 1982 and 1992 . While the level of persistence in the term structure $(\rho)$ is very similar across countries in his study, the size of the reaction coefficient $(\beta)$ is significantly different and is higher for Japan than for countries such as the United States. This paper will estimate equation (7) using the GMM framework.

\section{Methodology}

This paper employs the GMM technique, which has been used frequently in finance literature. This method has several advantages over other estimation techniques. First, it encompasses several standard approaches such as the ordinary least squares (OLS), two-stage least squares (2SLS), and instrumental variable (IV), and nonlinear simultaneous equation methods (see Hamilton [1994]). Furthermore, compared with classical regression methods such as the OLS, which require a spherical disturbance, the GMM requires relatively weaker assumptions for measuring the residual. By adjusting a covariance matrix, GMM estimators become robust to autocorrelation and heterogeneity in the residual. Similarly, endogeneity bias can also be dealt with by introducing instrumental variables. For estimation, equation (7) can be expressed in compact form as follows:

$$
y=X \beta+u
$$

where $y$ is a $(T \times 1)$ vector and $X$ is a $(T \times n)$ matrix containing explanatory variables, which are assumed to be covariance stationary processes. ${ }^{18}$ The residual is $u$ and $E[X u]=0$, and $\beta$ is an $(n \times 1)$ vector of parameters of interest. When $Z$ is a $(T \times q)$ matrix of instrumental variables and $q>n$, GMM estimators $\beta$ satisfy the following orthogonal condition.

$$
E g_{t}(\beta)=E\left(Z_{t}\left(y_{t}-X_{t} \beta\right)\right)=E\left(Z_{t} u_{t}\right)=0
$$

The GMM estimator $(\hat{\beta})$ can be obtained by minimizing the following equation.

$$
Q(\beta)=\bar{g}(\beta)^{\prime} W \bar{g}(\beta)
$$

18. See Ogaki (1999) for one case where nonstationary variables can be estimated by the GMM. 
where $\bar{g}(\beta)$ is a $(q \times 1)$ vector with a sample mean of $g(\beta)$ (i.e., $\left.\bar{g}(\beta)=T^{-1} \sum_{t=1}^{T} g_{t}(\beta)\right)$. The $W$ is a $(q \times q)$ symmetric and positive definite weighting matrix, and plim $(\hat{W}-W)=0$. The GMM estimators then can be expressed as

$$
\hat{\beta}=\left(X^{\prime} Z W Z^{\prime} X\right)^{-1} X^{\prime} Z W Z^{\prime} y .
$$

When the residual is i.i.d., $\hat{\beta}$ is $\sqrt{T}$ consistent and asymptotically normally distributed. One condition necessary to obtain an asymptotically efficient estimator of $\beta$ is $W=\Omega^{-1}$ where $\Omega$ is a covariance matrix of $g(\beta)$, i.e.,

$$
\Omega=\sum_{s=1}^{T} \sum_{t=1}^{T} E\left(g_{t}(\hat{\beta}) g_{s}(\hat{\beta})^{\prime}\right) / T
$$

However, financial data often do not follow an i.i.d. process. In the presence of a residual $(u)$ with possible autocorrelation and heterogeneity, the optimal GMM estimators are obtained by calculating a consistent $W$. The heteroskedastic and autocorrelation consistent (HAC) robust weighting matrix is obtained using the method developed by Newey and West (1987).

$$
\hat{\Omega}_{H A C}=\hat{S}_{0}+\left(\sum_{j=1}^{k} w(j)\left(\hat{S}(j)+\hat{S}(j)^{\prime}\right), \quad \text { where } \hat{S}(j)=\frac{1}{T-k} \sum_{t=j+1}^{T} Z_{t} \hat{u}_{t} Z_{t-j}^{\prime} \hat{u}_{t-j}\right.
$$

The kernel $w(j)$ is the Bartlett kernel $(w(j)=1-(j / k+1)$ for $k \geq j \geq 0)$ (see Cushing and McGarvey [1999]). The estimated weighting matrix (12) is consistent when $k \rightarrow \infty$ as $T \rightarrow \infty$ and $k / T^{1 / 2} \rightarrow 0$. The Monte Carlo exercises suggest that the choice of the bandwidth parameter $k$ is more important than the type of kernel (Newey and West [1994]), and in this paper a nonparametric method of Newey and West is used to select the number of auto-covariance.

When there are more instruments than parameters (i.e., $q>n$ ), the appropriateness of the model, including the choice of instruments, can be checked using the over-identification test (Hansen [1982]).

$$
J=T \bar{g}_{T}\left(\hat{\beta}_{T}\right)^{\prime} W \bar{g}_{T}\left(\hat{\beta}_{T}\right) .
$$

This statistic is asymptotically distributed as $\chi^{2}$ with a degree of freedom equal to $q-n$. Based on this, we can conduct an over-identification test that is used as our standard diagnostic method.

Since there is no established theory by which to determine the composition of instrumental variables, the choice of instruments is often left to the researcher's judgment. However, Hamilton (1994) summarizes that the instruments should be correlated with explanatory variables but not with the residual term. Furthermore, the number of instruments should be parsimonious, because the asymmetric efficiency can be improved only when additional instruments bring about extra information. Thus, 
in addition to the constant term, this paper uses three lagged explanatory variables as instrumental variables.

\section{Data and Preliminary Empirical Results}

Data used in this paper are weekly and cover a sample period from January 5, 1990 to March 30, 2003. Given our interest in analyzing the effectiveness of different types of monetary policy, the performance of the term-structure model will be examined in several subsample periods.

All data were obtained from Bloomberg and are plotted in Figure 1. Short-term interest rates are gensaki rates with a maturity of one, two, and three months. Among other short-term rates, the call market rates are a natural choice to represent the short-term rates for our analysis because of their close links to monetary policy. However, gensaki rates are employed in this study, because early call market rate data were recorded to only two decimal points and many observations during the low interest rate period are zero, which makes model estimates impossible. These data are also used in Shikano (1985), Kim and Limpaphayom (1997), and Nagayasu (2002). Japanese yield-to-maturity data of JGBs (discount bonds) with maturities of three and five years (JGB3 and JGB5) are used to represent long-term rates here. ${ }^{19}$ As mentioned, the JGB market is important with regard to monetary policy in Japan,

Figure 1 Short-Term Interest Rates and JGB Yields

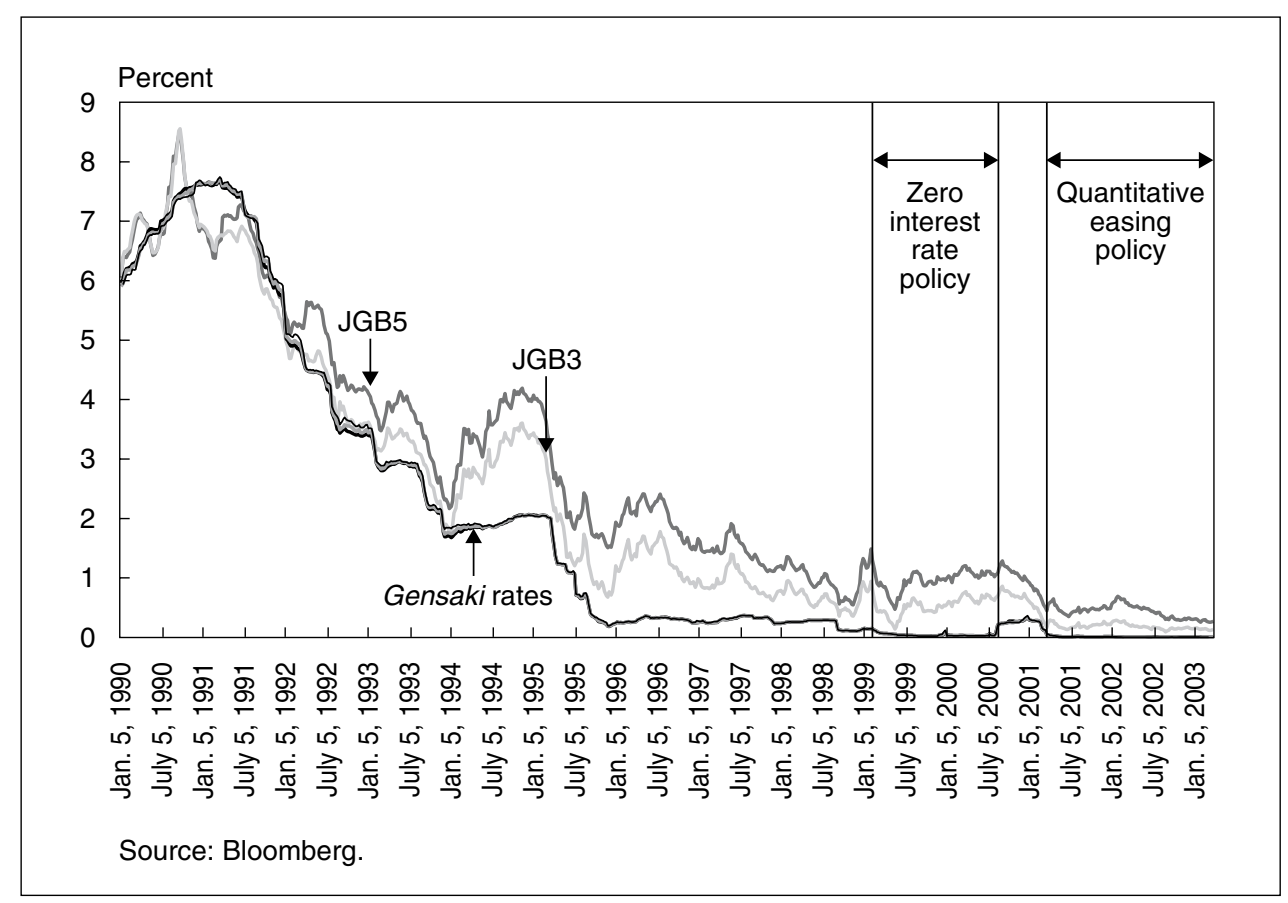

19. We have considered yield spreads based on a 10 -year-maturity JGB, but the result using these data is not reported here, since this variable is found to be nonstationary. 
since the purchase of government bonds is an integral part of the quantitative easing policy adhered to by the BOJ. Data are based on $r \times 100$ and $(R-r) \times 100$, where $R$ are $r$ are long- and short-term interest rates expressed as percentages per annum. The yield spreads and the first difference of gensaki rates are shown in Figure 2.

From Figure 1, we can make two observations. First, there was a discrepancy between short- and long-term interest rates during the low interest rate period. This gap became even more pronounced during the zero interest rate policy than during the quantitative easing policy period, thus indicating that these assets are not a perfect substitute. Second, the data show an increasing trend in JGB returns during the zero interest rate period. While ex post returns are on average zero percent, ${ }^{20}$ there was a tendency for expected future interest rates to increase. ${ }^{21}$ This can be analyzed by rewriting equation (2) as

$$
R_{n, t}-R_{n, t-1}=\frac{1}{n} \sum_{j=0}^{n-1} E_{t}\left(\Delta r_{1, t+j}\right)+\Delta \phi_{t}
$$

This equation states that an increase in long-term interest rates should be reflected in a rise in the future short-term rates. We have calculated the average (ex post) expected short-term rate using spot gensaki rates. Our calculation does not include

Figure 2 Short-Term Rates and Yield-Spread Dynamics

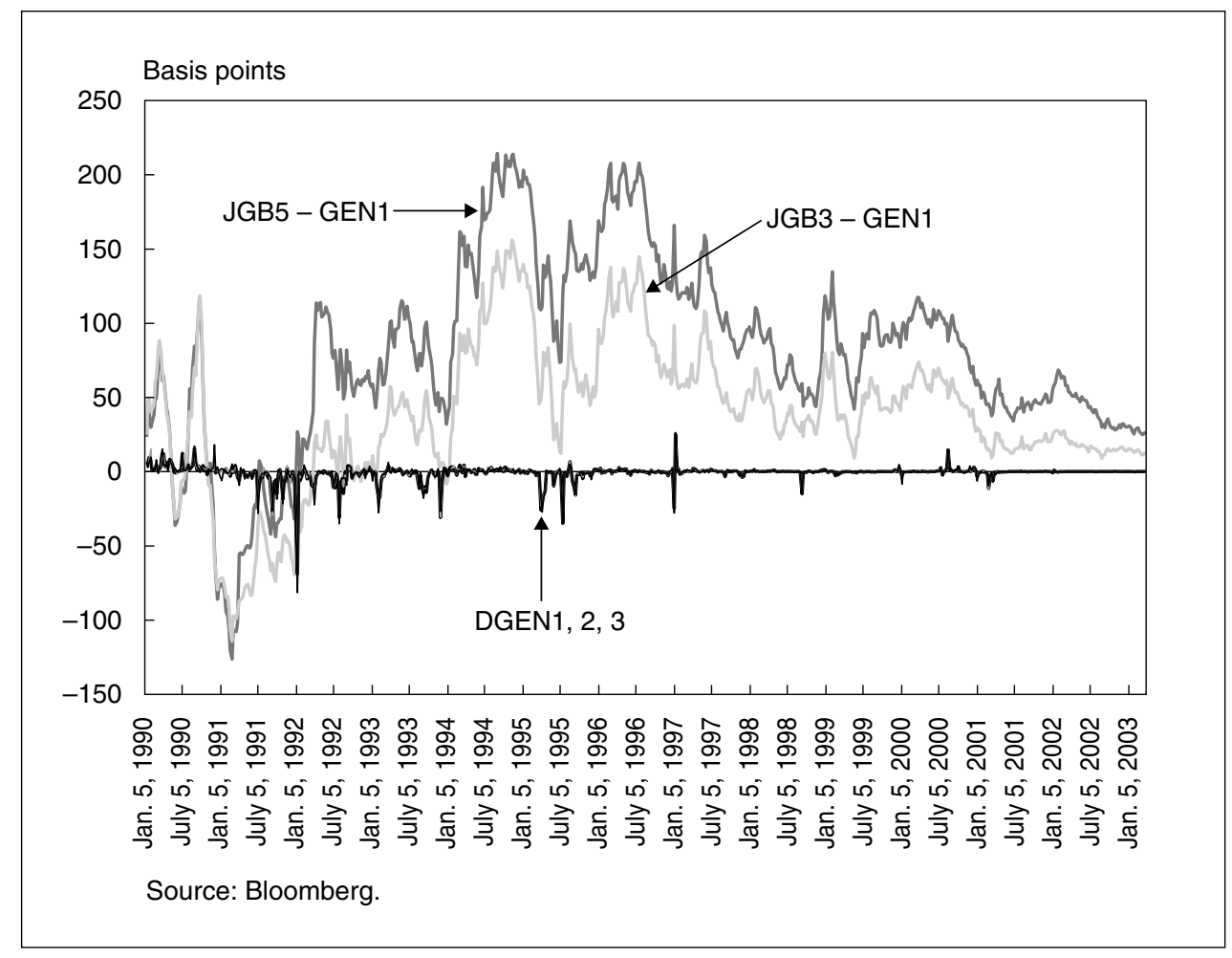

20. The $t$-statistic to test that the mean of data is equal to zero ranges from -1.118 to 1.261.

21 . Here we ignore the term premium, since it is difficult to quantify. 
observations between the zero interest rate and quantitative easing policies, since the removal of the zero interest rate policy was not generally anticipated according to a survey conducted by the Nippon Life Insurance Research Institute. ${ }^{22}$ Our calculations are therefore based on

$$
\begin{aligned}
& \Delta r_{t}^{e x}=\frac{1}{70+x}\left(\Delta r_{t}+\Delta r_{t+1}+\cdots+\Delta r_{t+70+x}\right) \\
& \Delta r_{t+1}^{e x}=\frac{1}{69+x}\left(\Delta r_{t+1}+\Delta r_{t+2}+\cdots+\Delta r_{t+69+x}\right)
\end{aligned}
$$

where $x$ is the number of extra observations remaining. Figure 3 shows these rates for the first 70 weeks after implementation of the zero interest rate and quantitative easing policies. An abrupt decline in ex post interest rates reflects a substantial increase in the BOJ's provision of liquidity to the market in an effort to offset Year 2000 (Y2K) uncertainty in financial markets.

This figure shows that ex post return data are at less than zero percent at the beginning of the implementation of the monetary policies, and thus the zero interest rate and quantitative easing policies were initially perceived as credible and were expected to last for some considerable time. However, this phenomenon changes over time. Apparently, there is usually an increasing trend in the ex post short-term rates during low interest rate periods, but this trend was absent during the quantitative easing policy. This indicates that, while it is statistically insignificant, some investors anticipated a change in the zero interest rate policy. This finding is consistent with Marumo et al. (2003), who calculate the probability of the zero interest rate policy being removed, and conclude that after August 2000 a shift occurred in the distribution of expectations; investors indeed had anticipated a policy change. In contrast, the relatively constant ex post rate during the quantitative easing policy would suggest that this measure was expected to last some time. This latter observation is generally consistent with previous research (Okina and Shiratsuka [2004]).

Table 1 summarizes the basic time-series properties of the data, where the transition periods $A$ and $B$ are combined. This table suggests that interest rate changes are statistically indifferent from zero during the low interest rate period, and are on average smallest during quantitative easing. The low levels of these variables during this period furthermore demonstrate that monetary policies were successful in maintaining low short-term rates. In addition, volatility measured using standard deviation as a benchmark was three to four times higher during the transition period. Similarly, volatility in spreads was found to be smaller during the duration of the quantitative easing policy than during the zero interest rate policy. In short, both interest rates and yield spreads changed most radically during the transition period.

22. It goes without saying that results are sensitive to this assumption. See Kubo (2001) for the definition of the index based on the survey to understand how money policy was perceived by the public. He also explains the dynamics of this index over time. 
Figure 3 Change in Ex Post Gensaki Rates

[1] Ex Post Gensaki One-Month Rate (Average)

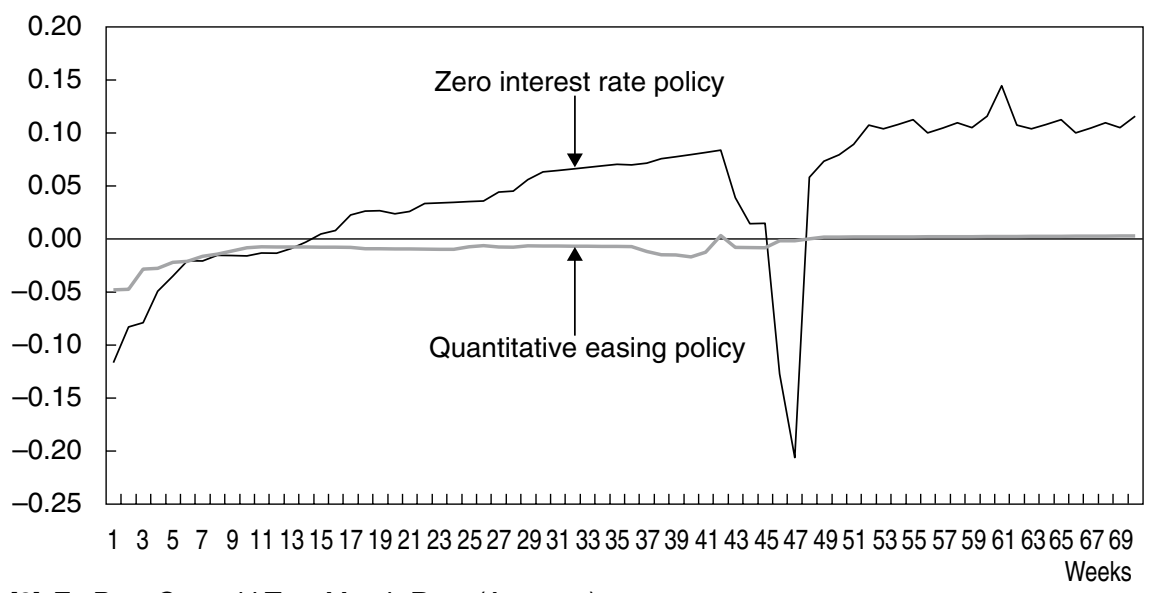

[2] Ex Post Gensaki Two-Month Rate (Average)
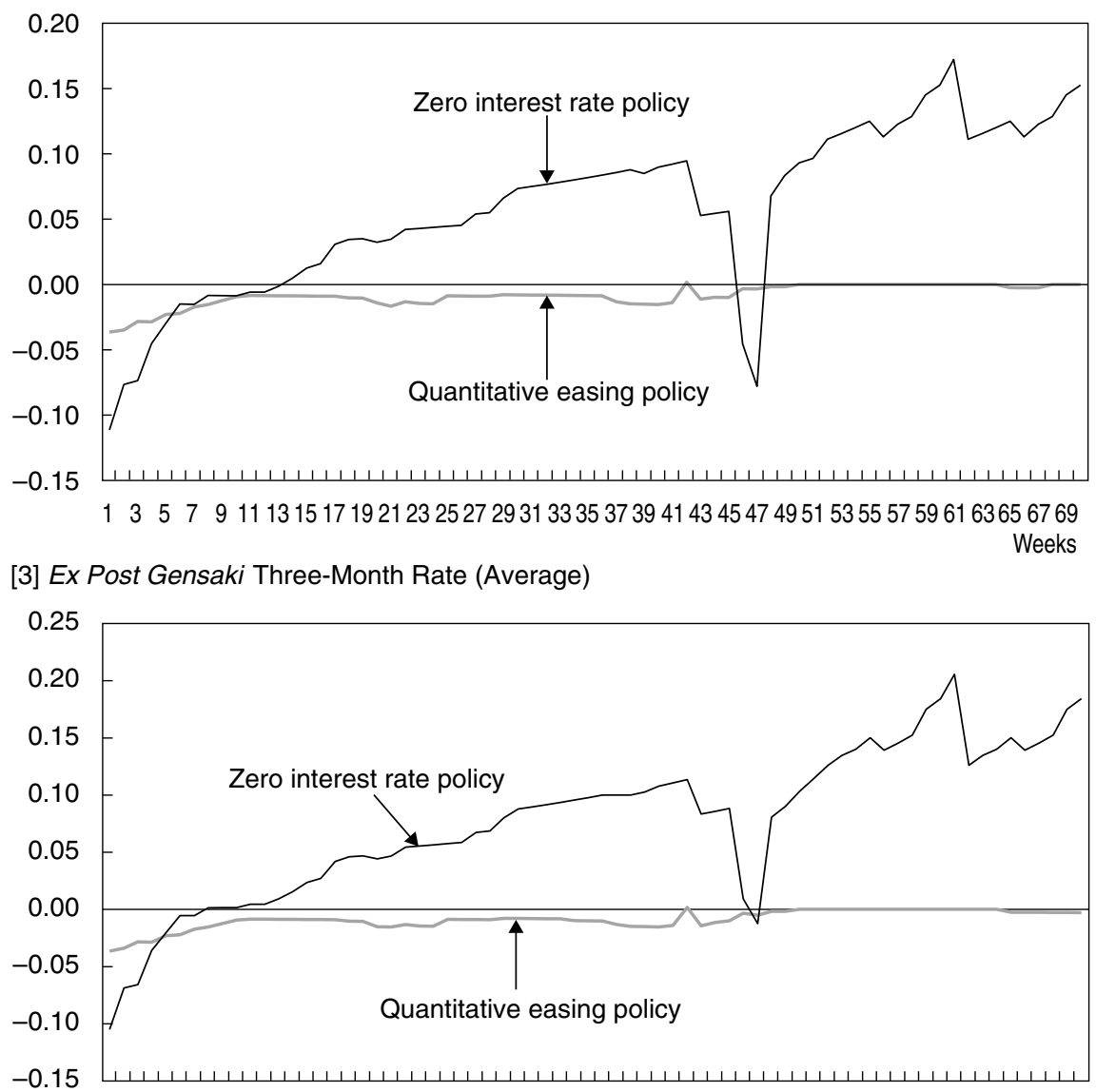

13579111315171921232527293133353739414345474951535557596163656769 Source: Bloomberg. 
Table 1 Data Properties

\begin{tabular}{|c|c|c|c|c|c|c|}
\hline & Mean & $\begin{array}{c}\text { Mean }=0 \\
t \text {-value }\end{array}$ & Std. dev. & Mean & $\begin{array}{c}\text { Mean }=0 \\
t \text {-value }\end{array}$ & Std. dev. \\
\hline & \multicolumn{3}{|c|}{ Full period } & \multicolumn{3}{|c|}{ Transition period } \\
\hline $\begin{array}{l}\text { DGEN1 } \\
\text { DGEN2 } \\
\text { DGEN3 }\end{array}$ & $\begin{array}{l}-0.851 \\
-0.854 \\
-0.862\end{array}$ & $\begin{array}{l}-3.903^{\star *} \\
-4.134^{\star *} \\
-4.361^{\star *}\end{array}$ & $\begin{array}{l}5.713 \\
5.414 \\
5.179 \\
\end{array}$ & $\begin{array}{l}-1.206 \\
-1.210 \\
-1.221\end{array}$ & $\begin{array}{l}-3.878^{\star \star} \\
-4.106^{\star \star} \\
-4.335^{\star \star}\end{array}$ & $\begin{array}{l}6.765 \\
6.408 \\
6.126 \\
\end{array}$ \\
\hline $\begin{array}{l}\text { JGB3 - GEN1 } \\
\text { JGB5 - GEN1 } \\
\text { JGB3 - GEN2 } \\
\text { JGB5 - GEN2 } \\
\text { JGB3 - GEN3 } \\
\text { JGB5 - GEN3 }\end{array}$ & $\begin{array}{l}38.263 \\
80.287 \\
39.422 \\
81.446 \\
40.114 \\
82.138\end{array}$ & $\begin{array}{l}20.756^{\star \star} \\
33.494^{\star \star} \\
21.757^{\star \star} \\
34.107^{\star *} \\
22.488^{\star \star} \\
34.536^{\star \star}\end{array}$ & $\begin{array}{l}48.318 \\
62.828 \\
47.491 \\
62.589 \\
46.754 \\
62.338\end{array}$ & $\begin{array}{l}41.147 \\
87.210 \\
42.824 \\
88.887 \\
43.842 \\
89.905\end{array}$ & $\begin{array}{l}15.787^{\star \star} \\
26.175^{\star \star} \\
16.760^{\star \star} \\
26.850^{\star \star} \\
17.464^{\star \star} \\
27.315^{\star \star}\end{array}$ & $\begin{array}{l}56.686 \\
72.461 \\
55.571 \\
71.998 \\
54.599 \\
71.583\end{array}$ \\
\hline JGB5 - GEN3 & \multicolumn{3}{|c|}{ Zero interest rate policy } & \multicolumn{3}{|c|}{ Quantitative easing policy } \\
\hline $\begin{array}{l}\text { DGEN1 } \\
\text { DGEN2 } \\
\text { DGEN3 }\end{array}$ & $\begin{array}{l}-0.117 \\
-0.112 \\
-0.105\end{array}$ & $\begin{array}{r}0.305 \\
-1.042 \\
-1.090\end{array}$ & $\begin{array}{l}1.320 \\
0.945 \\
0.852 \\
\end{array}$ & $\begin{array}{l}-0.048 \\
-0.037 \\
-0.037\end{array}$ & $\begin{array}{l}-1.966 \\
-1.952 \\
-1.877\end{array}$ & $\begin{array}{l}0.255 \\
0.191 \\
0.199\end{array}$ \\
\hline $\begin{array}{l}\text { JGB3 - GEN1 } \\
\text { JGB5 - GEN1 } \\
\text { JGB3 - GEN2 } \\
\text { JGB5 - GEN2 } \\
\text { JGB3 - GEN3 } \\
\text { JGB5 - GEN3 }\end{array}$ & $\begin{array}{l}49.281 \\
92.211 \\
49.290 \\
92.220 \\
49.233 \\
92.164\end{array}$ & $\begin{array}{l}29.299^{\star \star} \\
48.593^{\star \star} \\
29.466^{\star \star} \\
48.778^{\star \star} \\
29.597^{\star \star} \\
48.941^{\star \star}\end{array}$ & $\begin{array}{l}14.855 \\
16.759 \\
14.773 \\
16.698 \\
14.691 \\
16.632\end{array}$ & $\begin{array}{l}17.513 \\
42.832 \\
17.506 \\
42.825 \\
17.492 \\
42.812\end{array}$ & $\begin{array}{l}40.587^{\star \star} \\
39.854^{\star \star} \\
40.501^{\star \star} \\
39.811^{\star \star} \\
40.506^{\star \star} \\
39.799^{\star \star}\end{array}$ & $\begin{array}{r}4.400 \\
10.960 \\
4.408 \\
10.970 \\
4.404 \\
10.970\end{array}$ \\
\hline
\end{tabular}

Notes: For presentation purposes, the transition period in this table consists of the transition periods $A$ and $B$, which are defined in the main text.

${ }^{* *}$ indicates significance at the 1 percent level.

* indicates significance at the 5 percent level.

Source: Bloomberg.

\section{Empirical Results from the Term-Structure Model}

Section III of this paper discussed some statistical implications related to the expectations model of the term structure: the order of integration and causality tendencies of the data. Table 2 reports the results of the unit root tests, augmented Dickey-Fuller $(\mathrm{ADF})$ and Dickey-Fuller generalized least squares (DF-GLS), which were carried out to evaluate the null hypothesis of the unit root. Based on critical values suggested by

Table 2 Unit Root Tests

\begin{tabular}{|l|c|l|}
\hline & ADF & \multicolumn{1}{|c|}{ DF-GLS } \\
\hline DGEN1 & $-15.601(0)^{\star *}$ & $-1.942(8)^{\star}$ \\
DGEN2 & $-14.697(0)^{\star *}$ & $-2.203(8)^{\star}$ \\
DGEN3 & $-14.289(0)^{\star *}$ & $-1.996(8)^{\star}$ \\
\hline JGB3 - GEN1 & $-2.179(1)$ & $-2.130(1)^{\star}$ \\
JGB5 - GEN1 & $-1.910(1)$ & $-1.432(1)$ \\
JGB3 - GEN2 & $-2.173(1)$ & $-2.097(1)^{\star}$ \\
JGB5 - GEN2 & $-1.883(1)$ & $-1.370(1)$ \\
JGB3 - GEN3 & $-2.149(1)$ & $-1.997(1)^{\star}$ \\
JGB5 - GEN3 & $-1.859(1)$ & $-1.261(1)$ \\
\hline
\end{tabular}

Notes: ** indicates significance at the 1 percent level. * indicates significance at the 5 percent level.

Parentheses indicate number of lags. 
MacKinnon (1996) and Elliott, Rothenberg, and Stock (1996), the table suggests that the first difference of gensaki rates is stationary, while the yield spreads are less so. The yield spreads using three-year JGB (JGB3) data are reported to be stationary, but those with a five-year maturity (JGB5) follow the unit root process.

Next, causality between short-term rates and yield spreads is examined using the Granger noncausality test based on vector autoregression (VAR(6)). This test studies the null hypothesis of noncausality between these data. To determine whether or not unique causality exists, this test is implemented to study two null hypotheses: short-term interest rates do not cause a yield spread, and the spread does not cause short-term interest rate dynamics. Obtaining statistical evidence of unique causality from yield spreads to short-term rates requires rejection of the latter hypothesis and acceptance of the former.

According to the results presented in Table 3, only when the test is applied to the transition periods is there sufficient evidence to support yield spreads causing shortterm interest rates. It should be noted that this conclusion is not sensitive to the maturity lengths of gensaki rates. Once the short-term interest rates near zero percent (i.e., during the zero interest rate and quantitative easing policy periods), however, there is no evidence for unique causality, a finding consistent with economic theory.

To summarize, we have obtained two findings. First, the standard term-structure model is not adequate for analysis of interest rates when maturity lengths increase (i.e., five years) — a result consistent with Campbell and Hamao (1992). Second, as economic theory suggests, causality between short-term rates and the yield spread becomes opaque when the short-term rates near zero percent. Following the findings set out in our first conclusion, the analysis below focuses on short-term rate and yield spread relationships based on the three-year-maturity JGB data.

Table 3 Granger Non-Causality Tests

\begin{tabular}{|c|c|c|c|}
\hline & \multicolumn{2}{|l|}{$\mathrm{H}_{0}$} \\
\hline \multicolumn{2}{|l|}{ JGB3 - GEN1 $\rightarrow$ DGEN1 } & \multicolumn{2}{|l|}{ DGEN1 $\nrightarrow$ JGB3 - GEN1 } \\
\hline Full period & $38.477^{\star \star}$ & Full period & $14.681^{*}$ \\
\hline Transition period $\mathrm{A}$ & $32.218^{\star *}$ & Transition period $\mathrm{A}$ & 3.719 \\
\hline Transition period $\mathrm{B}$ & $29.225^{\star \star}$ & Transition period $\mathrm{B}$ & 10.488 \\
\hline Zero interest rate policy & 4.490 & Zero interest rate policy & 8.044 \\
\hline Quantitative easing policy & $21.936^{\star *}$ & Quantitative easing policy & $39.777^{* *}$ \\
\hline \multicolumn{2}{|l|}{ JGB3 - GEN2 $\rightarrow$ DGEN2 } & \multicolumn{2}{|l|}{ DGEN2 $\dashv$ JGB3 - GEN2 } \\
\hline Full period & $38.287^{\star \star}$ & Full period & $14.010^{\star \star}$ \\
\hline Transition period $\mathrm{A}$ & $43.886^{\star \star}$ & Transition period $\mathrm{A}$ & 4.322 \\
\hline Transition period $\mathrm{B}$ & $28.099^{\star \star}$ & Transition period B & 9.289 \\
\hline Zero interest rate policy & 4.698 & Zero interest rate policy & 9.316 \\
\hline Quantitative easing policy & $27.561^{\star \star}$ & Quantitative easing policy & $35.235^{\star *}$ \\
\hline \multicolumn{2}{|l|}{ JGB3 - GEN3 $\rightarrow$ DGEN3 } & \multicolumn{2}{|l|}{ DGEN3 $\nrightarrow$ JGB3 - GEN3 } \\
\hline Full period & $44.074^{\star \star}$ & Full period & $13.413^{\star}$ \\
\hline Transition period $\mathrm{A}$ & $50.961^{\star \star}$ & Transition period $\mathrm{A}$ & 3.559 \\
\hline Transition period $\mathrm{B}$ & $27.687^{\star *}$ & Transition period $\mathrm{B}$ & 8.482 \\
\hline Zero interest rate policy & 4.724 & Zero interest rate policy & 8.347 \\
\hline Quantitative easing policy & $30.326^{\star \star}$ & Quantitative easing policy & $34.610^{\star *}$ \\
\hline
\end{tabular}

Notes: ${ }^{* *}$ indicates significance at the 1 percent level.

* indicates significance at the 5 percent level. 
We will now conduct a more formal analysis of the term-structure model. For this purpose, equation (7) is estimated using the GMM with results reported in Table 4. The table shows that the results are indeed sensitive to the sample period. While the parameter, $\mu$, is statistically different from zero before the implementation of the zero interest rate policy, it becomes less so during transition period $\mathrm{B}$, and is insignificant during the low interest rate period. Thus, yield spreads had explanatory power in the early 1990s, but lost their usefulness in explaining the dynamics of short-term interest rates once short-term rates approached zero percent. This result remains unchanged even if different short-rate maturity lengths are used in the numerator when calculating yield spreads. Notably, the statistical insignificance of the term-structure model during the low interest rate period concurs largely with the conclusion from the Granger noncausality test.

Additionally, we investigate reasons why the performance of the term-structure model has changed over time. This analysis is carried out by breaking down parameter $\mu$ into its two components: $\rho$ (the persistence of the term premium) and $\beta$ (the reaction of the central bank). Our results suggest that whether or not $\mu=0$ depends on how the BOJ has responded to the yield spread $(\beta)$, since the term premium is always found to be an important determinant in the term-structure model.

Parameter $\beta$ is evaluated based on the BOJ's reaction function (equation [5]). This equation may be in an appropriate form when short-term rates can move up or down with the same probability. But when interest rates are around zero percent, we can expect that the probability of their going even lower is limited to the extent that

Table 4 Term-Structure Model (Equation [7])

\begin{tabular}{|c|c|c|c|c|}
\hline & Const. & $\mu$ & $\mathrm{N}-\mathrm{W}$ & $J$-statistics \\
\hline \multicolumn{5}{|l|}{ Full sample } \\
\hline JGB3 - GEN1 & $-1.540[0.609]^{\star}$ & $0.023[0.009]^{*}$ & 16 & 2.052 \\
\hline JGB3 - GEN2 & $-1.607[0.630]^{\star}$ & $0.022[0.009]^{*}$ & 16 & 1.598 \\
\hline JGB3 - GEN3 & $-1.653[0.654]^{\star}$ & $0.023[0.009]^{\star}$ & 17 & 1.595 \\
\hline \multicolumn{5}{|c|}{ Transition period $\mathrm{A}$} \\
\hline JGB3 - GEN1 & $-2.111[0.768]^{\star *}$ & $0.026[0.010]^{\star *}$ & 11 & 0.707 \\
\hline JGB3 - GEN2 & $-2.260[0.822]^{\star *}$ & $0.025[0.010]^{*}$ & 11 & 0.607 \\
\hline JGB3 - GEN3 & $-2.063[0.820]^{\star}$ & $0.023[0.009]^{*}$ & 11 & 1.697 \\
\hline \multicolumn{5}{|c|}{ Transition period $\mathrm{B}$} \\
\hline JGB3 - GEN1 & $-1.943[1.150]+$ & $0.025[0.015]+$ & 3 & 1.914 \\
\hline JGB3 - GEN2 & $-1.923[1.089]+$ & $0.024[0.014]+$ & 3 & 1.650 \\
\hline JGB3 - GEN3 & $-1.966[1.050]+$ & $0.025[0.013]+$ & 3 & 1.558 \\
\hline \multicolumn{5}{|c|}{ Zero interest rate policy } \\
\hline JGB3 - GEN1 & -0.190 [0.353] & $0.002[0.006]$ & 1 & 0.340 \\
\hline JGB3 - GEN2 & $-0.194[0.286]$ & $0.002[0.006]$ & 0 & 0.558 \\
\hline JGB3 - GEN3 & $-0.184[0.267]$ & $0.002[0.006]$ & 2 & 0.296 \\
\hline \multicolumn{5}{|c|}{ Quantitative easing policy } \\
\hline JGB3 - GEN1 & $0.068[0.076]$ & $-0.005[0.005]$ & 7 & 1.963 \\
\hline JGB3 - GEN2 & $0.066[0.082]$ & $-0.006[0.006]$ & 7 & 1.067 \\
\hline JGB3 - GEN3 & $0.066[0.085]$ & $-0.006[0.006]$ & 7 & 0.291 \\
\hline
\end{tabular}

Notes: ${ }^{* *}$ indicates significance at the 1 percent level.

* indicates significance at the 5 percent level.

+ indicates significance at the 10 percent level.

Brackets indicate standard errors. 
nominal interest rates are bounded at zero percent. In this case, the application of a standard approach such as the OLS will yield biased and inconsistent estimates. Therefore, following Iwata and Wu (2001) and Kato and Nishiyama (2004), equation (5) could be calculated using the censored normal regression model (Tobit). The short-term rates that are censored below zero percent have the following form:

$$
r_{1, t}= \begin{cases}r_{1, t}^{*}=\frac{\alpha}{1+\beta} r_{1, t-1}+\frac{\beta}{1+\beta} R_{n, t}+\frac{1}{1+\beta} u_{t} & \text { if } r_{1, t}^{*} \geq 0 \\ 0 & \text { if } r_{1, t}^{*}<0\end{cases}
$$

The first equation in (14) is another form of equation (5), and the residual maintains the normal distribution. Equation (14) is estimated using the maximum likelihood method. The threshold level in this study may be arbitrary, but is within the range that previous researchers have employed (Iwata and Wu [2001] and Kato and Nishiyama [2004]) and appears to be reasonable given that the nominal interest rates reached almost zero percent. The censored point of zero percent indicates that we allow a zero probability that nominal interest rates fall below zero percent.

Table 5 summarizes our findings and shows that the parameter $(\beta)$ is statistically significant only during the transition period. During the low interest rate period, the

Table 5 Term-Structure Model (Equation [5])

\begin{tabular}{|c|c|c|c|c|}
\hline & \multicolumn{4}{|c|}{ Tobit } \\
\hline & Const. & $\alpha /(1+\beta)$ & $\beta /(1+\beta)$ & $\sigma$ \\
\hline \multicolumn{5}{|l|}{ Full sample } \\
\hline JGB3 - GEN1 & $-0.024[0.004]^{\star \star}$ & $0.969[0.007]^{\star \star}$ & $0.033[0.007]^{\star \star}$ & $0.040[0.004]^{\star \star}$ \\
\hline JGB3 - GEN2 & $-0.024[0.004]^{\star *}$ & $0.970[0.006]^{\star *}$ & $0.032[0.006]^{\star \star}$ & $0.037[0.004]^{* *}$ \\
\hline JGB3 - GEN3 & $-0.023[0.004]^{\star *}$ & $0.970[0.006]^{\star *}$ & $0.031[0.006]^{* *}$ & $0.035[0.004]^{\star *}$ \\
\hline \multicolumn{5}{|c|}{ Transition period $\mathrm{A}$} \\
\hline JGB3 - GEN1 & $-0.064[0.010]^{\star \star}$ & $0.972[0.007]^{\star \star}$ & $0.043[0.007]^{\star \star}$ & $0.048[0.005]^{\star \star}$ \\
\hline JGB3 - GEN2 & $-0.066[0.010]^{\star *}$ & $0.963[0.006]^{\star \star}$ & $0.052[0.008]^{\star \star}$ & $0.042[0.003]^{* *}$ \\
\hline JGB3 - GEN3 & $-0.067[0.009]^{\star *}$ & $0.961[0.005]^{\star \star}$ & $0.053[0.007]^{\star *}$ & $0.039[0.003]^{\star *}$ \\
\hline \multicolumn{5}{|c|}{ Transition period B } \\
\hline JGB3 - GEN1 & $0.016[0.013]$ & $0.825[0.074]^{\star \star}$ & $0.032[0.011]^{\star \star}$ & $0.027[0.005]^{\star \star}$ \\
\hline JGB3 - GEN2 & $0.016[0.013]$ & $0.819[0.076]^{\star \star}$ & $0.033[0.011]^{\star \star}$ & $0.027[0.005]^{\star *}$ \\
\hline JGB3 - GEN3 & $0.016[0.013]$ & $0.818[0.075]^{\star \star}$ & $0.033[0.010]^{\star *}$ & $0.027[0.005]^{\star *}$ \\
\hline \multicolumn{5}{|c|}{ Zero interest rate policy } \\
\hline JGB3 - GEN1 & $0.011[0.008]$ & $0.752[0.123]^{\star *}$ & $-0.005[0.008]$ & $0.012[0.008]^{\star \star}$ \\
\hline JGB3 - GEN2 & $0.007[0.004]$ & $0.796[0.055]^{\star \star}$ & $-0.001[0.005]$ & $0.012[0.002]^{\star *}$ \\
\hline JGB3 - GEN3 & $0.006[0.004]$ & $0.807[0.044]^{\star *}$ & $0.001[0.005]$ & $0.018[0.010]^{* *}$ \\
\hline \multicolumn{5}{|c|}{ Quantitative easing policy } \\
\hline JGB3 - GEN1 & $0.001[0.001]$ & $0.836[0.085]^{\star \star}$ & $-0.000[0.004]$ & $0.001[0.000]^{\star \star}$ \\
\hline JGB3 - GEN2 & $-0.000[0.001]$ & $0.908[0.032]^{\star *}$ & $0.002[0.004]$ & $0.010[0.001]^{\star *}$ \\
\hline JGB3 - GEN3 & $0.000[0.001]$ & $0.893[0.026]^{\star \star}$ & $-0.001[0.003]$ & $0.001[0.000]^{\star *}$ \\
\hline
\end{tabular}

Notes: The Tobit model is based on the following log-likelihood function:

$$
\ln L=\sum_{y>0}-0.5\left[\ln (2 \pi)+\ln \sigma^{2}+\frac{\left(y_{t}-\beta^{\prime} x_{t}\right)^{2}}{\sigma^{2}}\right]+\sum_{y_{t}=0} \ln \left[1-\Phi\left(\frac{\beta^{\prime} x_{t}}{\sigma}\right)\right],
$$

where $\Phi(\bullet)$ is the standard normal cumulative distribution function, $y$ denotes a change in short-term interest rates, $x$ is a vector containing the right-hand-side variables of the equation, and $\beta$ is a vector of parameters.

** indicates significance at the 1 percent level.

Brackets indicate standard errors. 
size of this parameter decreases and is statistically insignificant. Our estimate of $\beta$ is lower than that found by Kugler (1997), and based on the policy reaction function of the central bank, we could argue that this result reflects the non-reaction of the BOJ to yield spread changes during the low interest rate period.

In contrast to $\beta$, the parameter, $\rho$, is statistically significant regardless of which sample period is studied (Table 6). Furthermore, this parameter is close to but less than one, showing persistence in the term premium regardless of sample period. The value of $\rho$ is in line with that reported by Kugler (1997). Thus, it can be concluded that the BOJ's lack of reaction to the yield spread seems to explain the significance of $\mu$.

These results indicate that, during the low interest rate period, the long-term rate is determined largely by the term premium. Therefore, under the low interest rate policy, it is very difficult for the BOJ to influence (and in particular to reduce) the long-term rate. This supports a nonlinear relationship between short- and long-rates as discussed in Ruge-Murcia (2002).

Our analysis so far using gensaki rates and JGBs of three-year maturity may be regarded as focusing on the relatively long end of the term structure. Generally, it is believed that the amount of information contained in the long end is different from that in the short end. Previous research signals that the long end of the term structure tends to contain more information useful for predicting economic activities such as inflation and economic growth. Therefore, to check the sensitivity of our previous result to the maturity length, we have repeated the same exercises using the Tokyo

Table 6 Term-Structure Model (Equation [6])

\begin{tabular}{|c|c|c|c|c|c|}
\hline & Const. & $\rho$ & $\begin{array}{c}\chi^{2}(1) \\
\mathrm{H}_{0}: \rho=1\end{array}$ & $\mathrm{~N}-\mathrm{W}$ & $J$-statistics \\
\hline \multicolumn{6}{|l|}{ Full sample } \\
\hline JGB3 - GEN1 & $0.772[0.525]$ & $0.974[0.009]^{\star \star}$ & $8.140^{\star \star}$ & 2 & 3.264 \\
\hline JGB3 - GEN2 & $0.819[0.511]$ & $0.974[0.009]^{\star *}$ & $8.206^{\star \star}$ & 2 & 2.960 \\
\hline JGB3 - GEN3 & $0.853[0.503]+$ & $0.973[0.010]^{\star \star}$ & $8.773^{\star \star}$ & 3 & 3.376 \\
\hline \multicolumn{6}{|c|}{ Transition period $\mathrm{A}$} \\
\hline JGB3 - GEN1 & $0.320[0.798]$ & $0.979[0.011]^{\star *}$ & $3.649+$ & 5 & 3.560 \\
\hline JGB3 - GEN2 & $0.400[0.780]$ & $0.979[0.011]^{\star *}$ & $3.569+$ & 5 & 3.378 \\
\hline JGB3 - GEN3 & $0.350[0.744]$ & $0.976[0.011]^{\star \star}$ & $4.385^{\star}$ & 4 & 3.401 \\
\hline \multicolumn{6}{|c|}{ Transition period $\mathrm{B}$} \\
\hline JGB3 - GEN1 & $3.913[1.938]^{\star}$ & $0.943[0.027]^{\star *}$ & $4.354^{*}$ & 8 & 2.112 \\
\hline JGB3 - GEN2 & $4.161[1.974]^{\star}$ & $0.940[0.028]^{\star *}$ & $4.766^{\star}$ & 8 & 1.738 \\
\hline JGB3 - GEN3 & $0.392[0.761]$ & $0.977[0.011]^{\star *}$ & $3.963^{*}$ & 4 & 3.634 \\
\hline \multicolumn{6}{|c|}{ Zero interest rate policy } \\
\hline JGB3 - GEN1 & $4.558[3.281]$ & $0.894[0.064]^{\star \star}$ & $2.765+$ & 6 & 2.924 \\
\hline JGB3 - GEN2 & $4.333[3.164]$ & $0.898[0.062]^{\star *}$ & $2.721+$ & 7 & 2.823 \\
\hline JGB3 - GEN3 & $4.447[3.110]$ & $0.896[0.061]^{\star *}$ & $2.929+$ & 8 & 2.617 \\
\hline \multicolumn{6}{|c|}{ Quantitative easing policy } \\
\hline JGB3 - GEN1 & $2.545[0.895]^{\star \star}$ & $0.839[0.048]^{\star \star}$ & $11.190^{\star *}$ & 5 & 1.212 \\
\hline JGB3 - GEN2 & $2.545[0.824]^{\star *}$ & $0.839[0.044]^{\star *}$ & $13.149^{\star \star}$ & 5 & 1.340 \\
\hline JGB3 - GEN3 & $2.556[0.816]^{\star \star}$ & $0.838[0.044]^{\star *}$ & $13.519^{\star *}$ & 5 & 1.352 \\
\hline
\end{tabular}

Notes: ${ }^{* *}$ indicates significance at the 1 percent level.

* indicates significance at the 5 percent level.

+ indicates significance at the 10 percent level.

Brackets indicate standard errors. 
Interbank Offered Rate (TIBOR) data. ${ }^{23}$ This data set covers maturities of one, two, three, six, nine, and 12 months, and enables us to analyze the performance of the short end of the term structure.

The results from the TIBOR data are reported in Tables $7-9$, where those during transition period $A$ are not included due to the lack of adequate sample size. (The TIBOR data are available from 1995 onward.) Table 7 shows the poor performance of the term-structure model regardless of the combination of interest rates used to calculate the yield spreads. This result is in sharp contrast to that obtained from the long end of the term-structure model using gensaki rates and JGBs, but is consistent with previous findings obtained elsewhere that the short end of the term-structure model performs less well than the long-end model.

Unlike the case of the long end of the term structure, this poor performance is attributable largely to the absence of the persistent term premium (Table 8). Since Table 9 shows that the yield spread contains information useful for prediction particularly during the transition period, the significance of this variable does not seem to be a key factor leading to our conclusion. However, it should be noted that the information content $(\beta)$ of this variable seems to be less significant during the low interest rate period than during the time of the transition. This finding is generally consistent with empirical evidence we found using the longer end of the term-structure model.

Table 7 Term-Structure Model (Equation [7]): TIBOR

\begin{tabular}{|c|c|c|c|c|}
\hline & Const. & $\mu$ & $\mathrm{N}-\mathrm{W}$ & $J$-statistics \\
\hline \multicolumn{5}{|l|}{ Transition period $\mathrm{B}$} \\
\hline TIBOR12M - TIBOR1M & $-0.339[0.970]$ & $0.014[0.034]$ & 1 & 2.000 \\
\hline TIBOR12M - TIBOR2M & $0.079[0.906]$ & $0.004[0.041]$ & 5 & 2.733 \\
\hline TIBOR12M - TIBOR3M & $-0.217[0.747]$ & $0.014[0.042]$ & 7 & 1.272 \\
\hline TIBOR12M - TIBOR6M & $-0.169[0.765]$ & $0.003[0.076]$ & 5 & 0.402 \\
\hline TIBOR12M - TIBOR9M & $-0.029[0.715]$ & $-0.029[0.147]$ & 7 & 0.391 \\
\hline \multicolumn{5}{|l|}{ Zero interest rate policy } \\
\hline TIBOR12M - TIBOR1M & $-15.491[0.870]^{\star \star}$ & $0.864[0.520]+$ & 23 & 1.242 \\
\hline TIBOR12M - TIBOR2M & $-4.624[2.260]^{\star}$ & $0.294[0.228]$ & 5 & 0.302 \\
\hline TIBOR12M - TIBOR3M & $1.400[0.990]$ & $-0.090[0.065]$ & 2 & 5.477 \\
\hline TIBOR12M - TIBOR6M & $-0.856[1.343]$ & $0.113[0.160]$ & 3 & 1.434 \\
\hline TIBOR12M - TIBOR9M & $-0.523[0.988]$ & $0.178[0.332]$ & 1 & 0.935 \\
\hline \multicolumn{5}{|l|}{ Quantitative easing policy } \\
\hline TIBOR12M - TIBOR1M & $-2.259[1.009]^{\star}$ & $0.525[0.294]+$ & 9 & 0.817 \\
\hline TIBOR12M - TIBOR2M & $-0.787[0.582]$ & $0.264[0.173]$ & 6 & 2.678 \\
\hline TIBOR12M - TIBOR3M & $-0.302[0.427]$ & $0.146[0.186]$ & 5 & 1.647 \\
\hline TIBOR12M - TIBOR6M & $0.028[0.209]$ & $-0.007[0.174]$ & 4 & 3.906 \\
\hline TIBOR12M - TIBOR9M & $0.035[0.117]$ & $-0.070[0.225]$ & 3 & 2.905 \\
\hline
\end{tabular}

Notes: ${ }^{*}$ indicates significance at the 1 percent level.

* indicates significance at the 5 percent level.

+ indicates significance at the 10 percent level.

Brackets indicate standard errors. 
Table 8 Term-Structure Model (Equation [6]): TIBOR

\begin{tabular}{|c|c|c|c|c|c|}
\hline & Const. & $\rho$ & $\begin{array}{c}\chi^{2}(1) \\
H_{0}: \rho=1\end{array}$ & $\mathrm{~N}-\mathrm{W}$ & $J$-statistics \\
\hline \multicolumn{6}{|l|}{ Transition period B } \\
\hline TIBOR12M - TIBOR1M & $-1.385[0.900]$ & $0.064[0.043]$ & $478.809^{\star \star}$ & 9 & 1.956 \\
\hline TIBOR12M - TIBOR2M & $-1.325[0.874]$ & $0.079[0.045]+$ & $411.821^{* *}$ & 9 & 0.022 \\
\hline TIBOR12M - TIBOR3M & $-0.607[0.950]$ & $0.042[0.053]$ & $12.025^{\star \star}$ & 2 & 1.009 \\
\hline TIBOR12M - TIBOR6M & $-0.417[0.791]$ & $0.036[0.068]$ & $199.324^{* *}$ & 2 & 1.167 \\
\hline TIBOR12M - TIBOR9M & $-0.513[0.654]$ & $0.084[0.110]$ & $69.158^{\star *}$ & 1 & 0.434 \\
\hline \multicolumn{6}{|l|}{ Zero interest rate policy } \\
\hline TIBOR12M - TIBOR1M & -1.223 [0.964] & $0.038[0.067]$ & $208.362^{\star \star}$ & 9 & 1.128 \\
\hline TIBOR12M - TIBOR2M & $-2.447[1.439]+$ & $0.145[0.075]+$ & $128.636^{\star *}$ & 4 & 1.244 \\
\hline TIBOR12M - TIBOR3M & $-0.824[1.338]$ & $0.077[0.100]$ & $84.805^{\star \star}$ & 2 & 3.214 \\
\hline TIBOR12M - TIBOR6M & $-0.591[0.873]$ & $0.094[0.135]$ & $45.274^{\star \star}$ & 2 & 0.816 \\
\hline TIBOR12M - TIBOR9M & $-0.473[0.627]$ & $0.096[0.260]$ & $12.064^{\star *}$ & 0 & 0.446 \\
\hline \multicolumn{6}{|l|}{ Quantitative easing policy } \\
\hline TIBOR12M - TIBOR1M & $0.116[0.420]$ & $-0.013[0.088]$ & $134.057^{\star *}$ & 10 & 3.136 \\
\hline TIBOR12M - TIBOR2M & $0.182[0.488]$ & $-0.048[0.140]$ & $55.684^{* *}$ & 2 & 4.335 \\
\hline TIBOR12M - TIBOR3M & $0.174[0.279]$ & $-0.065[0.123]$ & $75.333^{\star *}$ & 3 & 4.171 \\
\hline TIBOR12M - TIBOR6M & $0.134[0.140]$ & $-0.099[0.123]$ & $79.717^{\star \star}$ & 4 & 4.192 \\
\hline TIBOR12M - TIBOR9M & $0.033[0.079]$ & $-0.038[0.165]$ & $39.343^{\star *}$ & 4 & 3.904 \\
\hline
\end{tabular}

Notes: ${ }^{* *}$ indicates significance at the 1 percent level.

+ indicates significance at the 10 percent level.

Brackets indicate standard errors.

Table 9 Term-Structure Model (Equation [5]): TIBOR

\begin{tabular}{|c|c|c|c|c|}
\hline & \multicolumn{4}{|c|}{ Tobit } \\
\hline & Const. & $\alpha /(1+\beta)$ & $\beta /(1+\beta)$ & $\sigma$ \\
\hline \multicolumn{5}{|l|}{ Transition period B } \\
\hline TIBOR12M - TIBOR1M & $-0.110[0.047]^{\star}$ & $0.933[0.070]^{\star \star}$ & $0.230[0.071]^{\star \star}$ & $0.072[0.006]^{\star \star}$ \\
\hline TIBOR12M - TIBOR2M & $-0.105[0.045]^{*}$ & $0.971[0.097]^{\star *}$ & $0.194[0.072]^{\star *}$ & $0.070[0.006]^{\star *}$ \\
\hline TIBOR12M - TIBOR3M & $-0.082[0.038]^{\star}$ & $0.844[0.057]^{\star *}$ & $0.269[0.082]^{\star *}$ & $0.059[0.005]^{\star *}$ \\
\hline TIBOR12M - TIBOR6M & $-0.052[0.031]+$ & $0.628[0.072]^{\star *}$ & $0.430[0.087]^{\star *}$ & $0.049[0.004]^{\star *}$ \\
\hline TIBOR12M - TIBOR9M & $-0.020[0.017]$ & $0.265[0.057]^{\star *}$ & $0.745[0.065]^{\star *}$ & $0.029[0.002]^{\star *}$ \\
\hline \multicolumn{5}{|l|}{ Zero interest rate policy } \\
\hline TIBOR12M - TIBOR1M & $0.045[0.062]$ & $1.633[0.945]+$ & $0.165[0.292]$ & $0.131[0.033]^{\star \star}$ \\
\hline TIBOR12M - TIBOR2M & $0.091[0.037]^{*}$ & $1.023[0.086]^{\star *}$ & $-0.290[0.145]^{*}$ & $0.069[0.014]^{\star *}$ \\
\hline TIBOR12M - TIBOR3M & $0.066[0.033]^{*}$ & $0.887[0.057]^{\star *}$ & $-0.111[0.108]$ & $0.037[0.004]^{\star *}$ \\
\hline TIBOR12M - TIBOR6M & $0.039[0.024]$ & $0.596[0.078]^{\star \star}$ & $0.222[0.068]^{\star \star}$ & $0.023[0.002]^{\star *}$ \\
\hline TIBOR12M - TIBOR9M & $0.022[0.008]^{\star *}$ & $0.312[0.070]^{\star *}$ & $0.584[0.060]^{\star *}$ & $0.011[0.001]^{* *}$ \\
\hline \multicolumn{5}{|l|}{ Quantitative easing policy } \\
\hline TIBOR12M - TIBOR1M & $0.018[0.007]^{\star \star}$ & $0.771[0.080]^{\star \star}$ & $-0.039[0.066]$ & $0.004[0.001]^{\star \star}$ \\
\hline TIBOR12M - TIBOR2M & $0.001[0.017]$ & $0.933[0.082]^{\star *}$ & $0.065[0.183]$ & $0.009[0.001]^{\star *}$ \\
\hline TIBOR12M - TIBOR3M & $-0.001[0.014]$ & $0.979[0.065]^{\star \star}$ & $0.044[0.128]$ & $0.007[0.001]^{\star *}$ \\
\hline TIBOR12M - TIBOR6M & $-0.008[0.008]$ & $0.714[0.094]^{\star \star}$ & $0.341[0.129]^{\star \star}$ & $0.004[0.000]^{\star *}$ \\
\hline TIBOR12M - TIBOR9M & $-0.007[0.004]+$ & $0.441[0.094]^{\star \star}$ & $0.607[0.103]^{\star \star}$ & $0.002[0.000]^{\star *}$ \\
\hline
\end{tabular}

Notes: ${ }^{* *}$ indicates significance at the 1 percent level.

* indicates significance at the 5 percent level.

+ indicates significance at the 10 percent level.

Brackets indicate standard errors. 


\section{Summary and Discussion}

This paper has examined recent Japanese monetary policy, including zero interest rate and quantitative easing policies, by applying high-frequency interest rate data to a term-structure model developed by McCallum (1994), which allows a timevarying term premium. While more research is needed, particularly to reflect the fact that interest rates move in response to factors that are not captured by the termstructure model, such as exchange rate and credit channels, this study has come to the following conclusions.

First, the term structure of interest rates proves to be a useful tool with which to analyze Japanese monetary policy, particularly during a high interest rate period. During the low interest rate period, however, the short-term rates remain close to zero percent, and the yield spread is unable to predict short-term rate dynamics. Our data show that, for the long-end model, this indicates that long-term rates are largely determined by the forward-term premium and that, in general, these rates are increasingly difficult for the $\mathrm{BOJ}$ to influence, since the interest rate channel is practically nonexistent.

Second, we analyzed why, during the low interest rate period, the yield spread becomes less relevant to the prediction of short-term interest rates. Our empirical results suggest that the BOJ's low-level response to the yield spread contributes to this result. Another factor in this effect is less persistence in the term premium in the short end of the term structure. Indeed, the short-end data comprising interest rates of less than one-year maturity length show no evidence for the significant persistent term premium, while the contrary result is obtained for the long end of the term structure. It thus seems to confirm the more significant existence of the term premium for the longer-end data.

Third, according to the ex post expected short-term rates, both the zero interest rate and quantitative easing policies were perceived to be credible immediately after implementation. Although statistically insignificant, however, there was an upward trend in the ex post interest rates during the zero interest rate policy period. This indicates that investors began to regard this policy as less credible as time went on. In contrast, such an upward trend was not observed during the quantitative easing policy period. In view of the low and declining levels of long rates during that time, this policy seems to be more credible than the zero interest rate policy.

Fourth, while we did not discuss at length the BOJ's practice of interest rate smoothing in the main text, our results also raise some persuasive evidence that such a practice was implemented more forcibly during the quantitative easing policy than during the zero interest rate policy. This is supported by the size of parameter $\alpha$ (equation [5]) that is found to be closer to one, in many cases, during the quantitative easing policy. Thus, it appears that the $\mathrm{BOJ}$ indeed has attempted to conduct interest rate smoothing in this period in an effort to stabilize Japanese financial markets. However, since the objective of the quantitative easing policy is to achieve a target level of (a component of) money that is incompatible with interest rate smoothing, the rationale of such a policy is rather unclear. In this regard, we believe that an allowance for more fluctuation in short-term rates appears to be more 
appropriate for transmitting the effects of monetary policy through interest rate and expectations channels. The level of long-term rates could be viewed as an intermediate target of monetary policy. Thus, given the absence of the interest rate channel at a time of low interest rates, a variation in short-term rates is expected to reactivate the term-structure relationship and be more effective in passing on the BOJ's stance on monetary policy to long-term interest rate data.

Finally, this study suggests that there are some limits in analyzing the term structure using a time-series technique. This is due to the fact that although the yield spreads using the longer-term (e.g., five-year-maturity) assets appear to follow the unit root process, changes in the short-term rates are stationary. This may well indicate that an application of the term-structure model consistent with economic theory could pose some problems when analyzing longer-term rates. In addition, thorough analysis of the recent decline in long-term rates is beyond the scope of the term-structure model, since it focuses only on interest rate and expectations channels, not the other ones that are discussed in the introduction. In this connection, a future study aimed at better capturing the stance of monetary policy during the quantitative easing policy period could be conducted. Although short-term interest rates may hold some of the relevant information, they do not completely explain the effects of the easing policy, because of the zero lower bound of nominal interest rates. 


\section{References}

Baig, Taimur, "Monetary Policy in a Deflationary Environment," in Tim Callen and Jonathan Ostry, eds. Ending the Lost Decade: Policies to Revive Japan's Stagnant Economy, Washington, D.C.: International Monetary Fund, 2003, pp. 206-223.

Blinder, Alan S., "Monetary Policy at the Zero Lower Bound: Balancing the Risks," Journal of Money, Credit and Banking, 32 (4), 2000, pp. 1093-1099.

Campbell, John Y., and Yasushi Hamao, "The Interest Rate Process and the Term Structure of Interest Rates in Japan," in Kenneth J. Singleton, ed. Japanese Monetary Policy, Chicago: University of Chicago Press, 1992, pp. 95-120.

_, and Robert J. Shiller, "Cointegration and Tests of Present Value Models," Journal of Political Economy, 95 (5), 1987, pp. 1062-1088.

Cecchetti, Stephen G., "The Case of the Negative Nominal Interest Rates: New Estimates of the Term Structure of Interest Rates during the Great Depression," Journal of Political Economy, 96 (6), 1988, pp. 1111-1141.

Cushing Matthew J., and Mary G. McGarvey, "Covariance Matrix Estimation," in Laszlo Matyas, ed. Generalized Methods of Moments Estimation, Cambridge: Cambridge University Press, 1999, pp. 63-95.

Elliott, Graham, Thomas J. Rothenberg, and James H. Stock, "Efficient Tests for an Autoregressive Unit Root," Econometrica, 64 (4), 1996, pp. 813-836.

Fujiki, Hiroshi, and Shigenori Shiratsuka, "Policy Duration Effect under the Zero Interest Rate Policy in 1999-2000: Evidence from Japan's Money Market Data," Monetary and Economic Studies, Institute for Monetary and Economic Studies, Bank of Japan, 20 (1), 2002, pp. 1-31.

Goodfriend, Marvin, "Financial Stability, Deflation, and Monetary Policy," Monetary and Economic Studies, 19 (S-1), Institute for Monetary and Economic Studies, Bank of Japan, 2001, pp. 143-176.

Hamilton, James, Time Series Analysis, Princeton: Princeton University Press, 1994.

Hansen, Lars Peter, "Large Sample Properties of Generalized Method of Moments Estimators," Econometrica, 50 (4), 1982, pp. 1029-1054.

Hosono, Kaoru, Shigeru Sugihara, and Tsuyoshi Mihira, Kin'yu Seisaku no Yukosei to Genkai (The Effectiveness and Limits of Monetary Policy), Tokyo: Toyo Keizai, 2001 (in Japanese).

International Monetary Fund, Japan-Staff Report for the 2003 Article IV Consultation, Washington, D.C.: International Monetary Fund, 2003 (forthcoming).

Iwata, Shigeru, and Shu Wu, "Estimating Monetary Policy Effects When Interest Rates Are Bounded at Zero," draft, Economics Department, University of Kansas, 2001.

Jung, Taehun, Yuki Teranishi, and Tsutomu Watanabe, "Zero Bound on Nominal Interest Rates and Optimal Monetary Policy,” working paper, Hitotsubashi University, 2001.

Kato, Ryo, and Shin-ichi Nishiyama, "Optimal Monetary Policy When Interest Rates Are Bounded at Zero," Journal of Economic Dynamics and Control, 2004 (forthcoming).

Kikugawa, Tadashi, and Kenneth J. Singleton, "Modeling the Term Structure of Interest Rates in Japan," Journal of Fixed Income, 4 (2), 1994, pp. 6-16.

Kim, Kenneth A., and Piman Limpaphayom, "The Effect of Economic Regimes on the Relation between Term Structure and Real Activity in Japan," Journal of Economics and Business, 49 (4), 1997, pp. 379-392.

Kimura, Takeshi, Hiroshi Kobayashi, Jun Muranaga, and Hiroshi Ugai, "The Effect of the Increase in Monetary Base on Japan's Economy at Zero Interest Rates: An Empirical Analysis," IMES Discussion Paper No. 2002-E-22, Institute for Monetary and Economic Studies, Bank of Japan, 2002.

Kubo, Hideya, “Atarashii Kin’yuseisaku no Wakugumi wo Saguru (Looking for a New Framework for Monetary Policy)," in Kazuo Ogawa and Heizo Takenaka, eds. Seisaku Kiki to Nihonkeizai (Policy Crises and the Japanese Economy), Tokyo: Nippon Hyoronsha, 2001 (in Japanese).

Kugler, Peter, "Central Bank Policy Reaction and the Expectations Hypothesis of the Term Structure," International Journal of Finance and Economics, 2 (3), 1997, pp. 217-224. 
- "The Term Premium, Time Varying Interest Rate Volatility and Central Bank Policy Reaction," Economics Letters, 76 (3), 2002, pp. 311-316.

MacKinnon, James G., "Critical Values for Cointegration Tests," in C. W. J. Granger and G. E. Mizon, eds. Long-Run Economic Relationships, Oxford: Oxford University Press, 1996, pp. 267-276.

Mankiw, N. Gregory, and Jeffrey A. Miron, "The Changing Behavior of the Term Structure of Interest Rates," Quarterly Journal of Economics, 101 (2), 1986, pp. 211-228.

Marumo, Kohei, Takashi Nakayama, Shinichi Nishioka, and Toshihiro Yoshida, "Zero Kinri-Ka niokeru Kinri no Kikankozo Moderu (The Term Structure Model under the Zero Interest Rate Policy)," Bank of Japan Capital Market Department Working Paper No. 2003-J-1, Bank of Japan, 2003 (in Japanese).

McCallum, Bennett T., "Monetary Policy and the Term Structure of Interest Rates," NBER Working Paper No. 4938, National Bureau of Economic Research, 1994.

Meltzer, Allan H., "Comments: What More Can the Bank of Japan Do?” Monetary and Economic Studies, 17 (3), Institute for Monetary and Economic Studies, Bank of Japan, 1999, pp. 189-191.

Nagayasu, Jun, "On the Term Structure of Interest Rates and Inflation in Japan," Journal of Economics and Business, 54 (5), 2002, pp. 505-523.

-, "The Effectiveness of Monetary Policy on Equity Prices in a Zero Interest Rate Environment," manuscript, Washington, D.C.: International Monetary Fund, 2003.

Newey, Whitney K., and Kenneth West, "A Simple, Positive Semi-Definite Heteroskedasticity and Autocorrelation Consistent Covariance Matrix," Econometrica, 55 (3), 1987, pp. 703-709.

, "Automatic Lag Selection in Covariance Matrix Estimation," Review of Economic Studies, 61 (4), 1994, pp. 631-653.

Ogaki, Masao, "GMM Estimation Techniques," in Laszlo Matyas, ed. Generalized Methods of Moments Estimation, Cambridge: Cambridge University Press, 1999, pp. 31-62.

Ogawa, Kazuo, and Heizo Takenaka, eds. Seisaku Kiki to Nihonkeizai (Policy Crises and the Japanese Economy), Tokyo: Nippon Hyoronsha, 2001 (in Japanese).

Okina, Kunio, and Shigenori Shiratsuka, "Policy Commitment and Expectation Formations: Japan's Experience under Zero Interest Rates," North American Journal of Economics and Finance, 15 (1), 2004, pp. 75-100 (forthcoming).

Reifschneider, David, and John C. Williams, "Three Lessons for Monetary Policy in a Low-Inflation Era," Journal of Money, Credit and Banking, 32 (4), 2000, pp. 936-966.

Ruge-Murcia, Francisco J., "Some Implications on the Zero Lower Bound on Interest Rates for the Term Structure and Monetary Policy,” Working Paper No. 06-2002, University of Montreal, 2002.

Saito, Makoto, Shigenori Shiratsuka, Tsutomu Watanabe, and Noriyuki Yanagawa, "Liquidity Demand and Asset Pricing: Evidence from the Periodic Settlement in Japan," IMES Discussion Paper No. 2001-E-21, Institute for Monetary and Economic Studies, Bank of Japan, 2001.

Shikano, Yoshiaki, "Expectations Theory and Term Structure of Interest Rates," Monetary and Economic Studies, 3 (1), Institute for Monetary and Economic Studies, Bank of Japan, 1985, pp. 47-70.

Shiller, Robert J., "The Volatility of Long-Term Interest Rates and Expectations Models of the Term Structure," Journal of Political Economy, 87 (6), 1979, pp. 1190-1219.

, "The Term Structure of Interest Rates," in B. M. Friedman and F. H. Hahn, eds. Handbook of Monetary Economics, Volume 1, 1990, pp. 629-722.

Shirakawa, Hiromichi, "Fluctuations in Yields on Bonds-A Reassessment of the Expectations Theory Based on Japanese and U.S. Data," Monetary and Economic Studies, 15 (2), Institute for Monetary and Economic Studies, Bank of Japan, 1987, pp. 71-117.

Thornton, Daniel L., "Testing the Expectations Hypothesis: Some New Evidence for Japan," Monetary and Economic Studies, 22 (2), Institute for Monetary and Economic Studies, Bank of Japan, 2004, pp. 45-70 (this issue). 
